\title{
DARI KRISIS NILAI TUKAR, ALTERNATIF PENJAMINAN SIMPANAN, PERAN LEMBAGA KEUANGAN MIKRO HINGGA MONEYLAUNDERING :
}

\author{
O verview
}

\author{
Halim Alamsyah *)
}

Pembaca mungkin akan menemukan bahwa overview kali ini agak berbeda dari yang biasanya. Kal au dal am bulletin-bul letin sebel umnya pembaca akan dapat segera menemukan adanya suatu benang merah dari berbagai tulisan-tulisan yang dimuat. Kali ini overview akan mengangkat beberapa subtopik penting yang diulas dal am paper-paper yang diterbitkan dalam bulletin ini. Tidak lain tujuannya adalah agar pembaca dapat memahami dengan lebih baik bagaimana sudut pandang dan solusi yang ditawarkan oleh para penulis.

Dengan kerangka analisis sedemikian ini maka overview akan kita mulai dengan melihat paper yang ditulis oleh Prof. Lepi Tarmidi mengenai krisis moneter di Indonesia, sebab-sebab, dampak, peran IMF, dan saran beliau'1). Tentu saja untuk dapat menemukan benang merah pemikiran beliau kita perlu menyelami dulu kerangka berpikir yang digunakannya. Bila kita membaca paper yang ditulis beliau maka pada dasarnya beliau mengatakan bahwa krisis yang berkepanjangan di Indonesia adalah ...krisis merosotnya nilai tukar Rp yang sangat tajam... (hal 3). Lalu beliau menyimpulkan bahwa akar permasalahan yang menyebabkan Indonesia mengalami krisis adalah sangat besarnya akumulasi utang swasta, terutama sejak awal tahun 1990-an. Patut dikemukakan bahwa beliau tidak melupakan peran berbagai faktor-faktor lainnya seperti inefisiensi di sektor riil, sistem perbankan yang lemah, struktur ekonomi yang monopolistis dan sebagainya. Namun, faktorfaktor tersebut sebenarnya telah lama ada sebel um krisis terjadi, dan menurut beliau, karena pengelolaan ekonomi makro yang baik hal-hal yang negatif tersebut tidak sampai menimbulkan krisis. Krisis baru terjadi akibat pengaruh penyakit menular dari Thailand yang kemudian menimbulkan krisiskepercayaan kepadakemampuan Indonesia untuk dapat mempertahankan sistem nilai tukar mengambang tetapi amat terkendali. Ketika disadari bahwa kemampuan Indonesia untuk membayar kembali utang swasta tersebutamatterbatas, baik akibat struktur utang yang relatif mahal dan berjangka pendek maupun karena kemampuan mengumpulkan devisa yang semakin berkurang akibat Rp overvalued, maka tembok penahan berupa fundamental ekonomi - a... pertumbuhan ekonomi tinggi, laju inflasi terkendali, tingkat pengangguran rendah, anggaran pemerintah yang sedikit surplus-

\footnotetext{
*) Halim Alamsyah, Deputi Kepala Urusan Riset Ekonomi dan Kebijakan Moneter, Bank Indonesia. Email : halamsyah@bi.go.id

1. Lepi T. Tarmidi, "Krisis Moneter Indonesia : Sebab, Dampak, Peran IMF dan Saran”, hal. 1
} 
yang selama bertahun-tahun dianggap cukup sehat akhirnya jebol juga. Terjadilah tekanan yang amat dalam terhadap Rp ketika arus balik modal keluar terjadi secara besar-besaran bersamaan dengan munculnya anggapan masyarakat-dalam dan luar negeri- bahwa rejim nilai tukar 'mengambang yang amat terkendali' tidak lagi dapat dipertahankan.

Sebenarnyalah kerangka analisis dari Prof. Tarmidi mirip dengan yang diutarakan oleh berbagai pakar ekonomi terutama yang menggunakan pemikiran pakar ekonomi Amerika Serikat Paul Krugman melalui papernya yang sederhana tetapi amat masjhur tentang A M odel of Balance of P ayment Crises (1979). Menurut prediksi berbagai model yang dikembangkan oleh al iran ini -terutamayang first generation models-, dalam suatu ekonomi yang terbuka dimana kursyang dianut bersifat tetap atau amat dikendal ikan maka ekspansi kredit domestik yang amat tinggidi sektor moneter (misalnyakarena defisit spending) secara cepat atau lambat akan mengaki batkan terkurasnya cadangan devisa. Secara implisit anal isis alaKrugmanian ingin mengatakan bahwa nilai tukar yang relatif tetap tersebut dapat menjadi overvalued akibat dari diabaikannya tekanan untuk melakukan devaluasi/ depresiasi ketika kegiatan ekonomi domestik cenderung memanas. A kibatnya rejim kurs yang dianut tidak akan dapat dipertahankan sehingga mendorong munculnya speculative attack yang pada akhirnyaakan mendorong diberlakukannyasistem nilai tukar mengambang bebas (lihat boks).

Tentu saja tidak seluruh pandangan Prof. Tarmidi mengikuti pandangan aliran Krugmanian. Satu perbedaan yang pokok adalah bahwa aliran Krugmanian sebenarnya berpendapat bahwa krisis nilai tukar yang terjadi pada dasarnya adalah cerminan dari fundamental ekonomi yang buruk (kebijakan kreditatau fiskal yang over-ekspansif, overvalued mata uang yang menyebabkan defisit pada neraca pembayaran). Sedangkan Prof. Tarmidi pada awal papernyatelah menyatakan bahwa krisis di Indonesia bukan karena fundamental yang buruk, baik makro maupun mikro, tetapi lebih karena munculnya krisis kepercayaan akibat dari terlalu besarnya utang swasta Indonesia. Secara tegas beliau malah mengatakan bahwa ....seandainya tidak ada serbuan terhadap dollar A merika Serikat ini, meskipun terdapat distorsi pada tingkat ekonomi mikro, ekonomi Indonesia tidak akan mengalami krisis...(hal 3). Patut dikemukakan bahwa beliau juga memperhitungkan pengaruh negatif dari berbagai faktor fundamental yang lemah terhadap krisis meskipun tidak ditekankan menjadi suatu topik yang dominan karena tersebar di sana-sini. Oleh karena itu dari saran-saran beliau akan tampak bahwa upaya menstabilkan nilai tukar Rp dan negosiasi utang menduduki peran yang amat penting bagi upaya meredam krisis ekonomi dewasa ini. Secara khusus beliau juga berpendapat bahwa Departemen Keuangan dan Bank Indonesia harus proaktif dalam menghadapi IMF Indonesia dengan mengajukan saran-sarannya sendiri dan menolak program-programekonomi yang tidak relevan dan cenderung merugikan Indonesia (hal 20-22).

Dalamkaitan dengan program stabilisasi yang dirancang Pemerintah bersama dengan IMF ini memang terdapat satu masalah yang amat berat yang harus dihadapi ketika krisis 


\section{Model generasi pertama serangan speculatif dalam sistem nilai tukar tetap:}

Permintaan uang di suatu ekonomi dapat dimodelkan (dalam log) menjadi:

$$
m^{d} \cdot p=-\alpha i+\beta y
$$

sedangkan sisi supply uang $\mathbf{m}^{\mathbf{s}}=\mathbf{r}+\mathbf{d}$ dimana $\mathbf{r}$ adalah net foreign asset dan $\mathbf{d}$ kredit domestik. Dalam kondisi keseimbangan $\mathrm{M}^{\mathrm{d}}=\mathrm{M}^{\mathrm{s}}$ maka persamaan (1) menjadi :

$r+d=p-\alpha \dot{a}+\beta y$

bila ekonomi kita terbuka dan relatif kecil di dunia internasional serta menganut sistem devisa bebas maka $\mathbf{p}=\mathbf{p}^{*}+\mathbf{s}$ dan $\mathbf{i}=\mathbf{i}^{*}+\mathbf{s}$, dimana tanda $*$ menandakan harga dan suku bunga internasional dan $\mathbf{s}$ adalah kurs. Ini berarti persamaan 2 menjadi:

$r+d=p^{*}+s-\alpha\left(i^{*}+s\right)+\beta y$

karena $\mathbf{p}^{*}$ dan $\mathbf{i}^{*}$ tidak dapat kita pengaruhi dan sistem kurs relatif tetap, persamaan 3 dapat disederhanakan menjadi:

$\mathbf{r}+\mathbf{d}=\beta \mathbf{y}$

bila analisis kita lakukan untuk jangka pendek maka kita dapat mengatakan pertumbuhan $y=0$. Ini berarti persamaan 4 menjadi $\mathbf{d}=\mathbf{- r}$. Artinya bahw a setiap pertambahan $\mathbf{d}$ (misalnya ekspansi kredit perbankan atau deficit spending) akan mendorong hilangnya cadangan devisa dalam jum lah yang sama. Jelaslah lama kelamaan cadangan devisa akan semakin terkuras dan kemampuan negara ini untuk mempertahankan kurs tetapnya akan dipertanyakan dan mengundang serangan spekulatif atas mata uangnya.

Pertanyaan lanjutannya adalah bila serangan tersebut akan dilakukan ? Tentu saja bila pasar menganggap kurs tetap yang dipertahankan tersebut telah overvalued dan pemerintah akhirnya akan kehabisan reserves bila terus mempertahankannya. Bila diasumsikan kurs $\mathbf{s}_{\mathbf{b}}$ adalah kurs bayangan bila $\mathbf{r}=0$ serta asumsi $\mathbf{p}^{*}, \mathbf{i}^{*}, \mathrm{~d} \mathbf{y}=0$ (untuk menyederhanakan) maka persamaan 3 di atas dapat ditulis kembali sebagai :

$\mathbf{d}=\mathbf{s}_{\mathrm{b}}-\alpha \mathbf{s}_{\mathrm{b}}$

Ini berarti kurs bayangan tersebut (shadow exchange rate) adalah:

$s_{b}=1 /(1-\alpha) . d \quad$

atau equivalen dengan $\mathbf{s}_{\mathbf{b}}=\boldsymbol{\alpha} \boldsymbol{\mu}+\mathbf{d}$ (bila dilinierkan). Selama $\mathbf{s}<\mathbf{s}_{\mathbf{b}}$ belum akan terjadi serangan spekulasi. Namun begitu s semakin mendekati atau sama dengan $\mathbf{s}$ maka serangan spekulatif akan semakin gencar sampai akhirnya sistem kurs tetap ditinggalkan. 
perbankan sedang menghebat terutama pada awal-awal tahun 1998. Pada waktu itu, pelarian simpanan (bank-runs) dari sistem perbankan telah terjadi dengan sangat luar biasa sehingga dalam waktu hanya beberapa minggu, jumlah yang ditarik dari sistem perbankan mencapai puluhan triliun Rp. Sementara Indonesia bel um mengenal suatu sistem asuransi atau penjaminan terhadap simpanan ataupun kewajiban dari sistem perbankan maka dapat diduga pelarian simpanan tersebut terus berlangsung hingga beberapa bulan dan akhirnya mengancam kehidupan perbankan nasional. Oleh karena itulah Pemerintah yang didukung oleh IMF harus memperkenalkan suatu program darurat yakni program penjaminan yang sifatnya menyeluruh (blanket guarantescheme) untuk mengembalikan kepercayaan masyarakat kepada sistem perbankan nasional.

Sistem penjaminan menyeluruh tersebut hingga dewasa ini masih terus berlaku. Dan barangkali setelah kita melihat perkembangan perbankan hingga saat ini dapat kita katakan bahwa tindakan darurat tersebut cukup efektif dalam menentramkan kekhawatiran masyarakat. Namun, seperti dikatakan oleh Maulana I brahim dan Agusmann'), praktis sulit untuk dipungkiri ... bahwa skim penjaminan pemerintah yang bersifat menyeluruh itu akan sangat memberatkan keuangan pemerintah, khususnya karenatidak sebandingnya nilai premi dengan cakupan penjaminan di samping adanya peluang untuk melakukan moral hazard (hal 32). Selanjutnya, mereka mengatakan dalam jangka panjang tampaknya perlu dicari alternatif lain yang memungkinkan terselenggaranyasuatu program penjaminan yang efisien dan efektif. Dalam kaitan inilah mereka menawarkan suatu konsep penjaminan yang dinamakan CrossGuarantee. Konsep cross guarantee ini pada hakikatnya adalah suatu konsep dimana bankbank saling menjamin satu dengan yang lainnya berdasarkan suatu cross-guarantee contract. Tidak ada campur tangan dari otoritas disini karena skim penjaminan diatur oleh kekuatan pasar (market-driven cross-guarantee). Konsekuensi dari swastanisasi ini adalah otoritas pengawasan perbankan akan berada di tangan swasta pula. Oleh karena itulah pada akhir makalah mereka penulis secara terbuka mengajukan sejumlah pertanyaan yang harus dijawab terlebih dahulu bila konsep ini ingin diterapkan di Indonesia.

Dalam makalah selanjutnya, Sumantoro Martowijoyo mengajak kita melihat permasalahan mikro yang selal u menjadi topik yang hangat di tengah-tengah situasi krisis³. Terlebih lebih lagi bilakitakaitkan dengan upaya mengurangi dampak negatif krisisterhadap golongan masyarakat yang berpendapat rendah dan amat rendah atau subsistence level. Penulis menyoroti permasalahan yang dihadapi lembaga keuangan mikro (LKM) di pedesaan dan faktor-faktor yang menurut penulis mempengaruhi kinerja lembaga keuangan mikro tersebut. A mat menarik untuk diketahui bahwa penulis menemukan bahwa faktor yang

2. Maulana Ibrahim dan Agusman, "Konsep Cross-Guarantee dalam Program Penjaminan dan Kemungkinan Penerapannya di Indonesia”, hal. 31

3. Sumantoro Martowijoyo, “Kinerja Lembaga Keuangan Mikro dan Perilaku Masyarakat Pedesaan”, hal. 45 
paling mempengaruhi kinerja LKM ini ternyata adalah jarak kelokasi nasabah dan selang waktu yang dibutuhkan untuk proses kredit. Selain itu, perilaku dari nasabah atau pengusaha mikro pedesaan cenderung menabung atau melunasi tunggakan kredit bila mereka mendapatkan kenaikan pendapatan. Atas berbagai temuannya tersebut penulis kemudian memberikan saran antara lain agar kebijakan pengembangan LKM memperhatikan kemungkinan membuka sebanyak mungkin pos pelayanan dan/ atau mengintensifkan kunjungan ke para nasabah LKM lapangan. Satu hal yang patut kita renungkan bersama adalah temuan penulis bahwa ternyata berbagai program Pemerintah untuk menyediakan kredit murah bersubsidi yang ada dewasa ini di pedesaan justru membuat posisi LKM seperti "telor di ujung tanduk". Selama hampir tiga dasawarsa dengan pendekatan pasar para LKM ini dapat terus lestari dan mandiri. Adanya berbagai program bersubsidi dari pemerintah tersebut justru memperlemah semangat keswadayaan masyarakat dan dikhawatirkan dapat merusak moralitas masyarakat pedesaan yang masi jujur.

Sejalan dengan hasil penelitian di atas maka dalam makalah yang ditulis oleh Satrio Wibowo $\mathrm{dkk}^{4}$. diteliti juga peran Perum Pegadaian dalam mempermudah kesulitan pembiayaan yang dihadapi oleh para pengusaha kecil. Penelitian ini menyajikan beberapa temuan menarik. Dalam masa krisis ternyata Perum Pegadaian menunjukkan kinerja yang semakin meningkat. Lonjakan kegiatan perum pegadaian selama masakrisis ini dialami di daerah Jakarta, Bandung, dan Yogyakarta sementara yang agak kurang berkembang berada di daerah Padang, M edan, Ujung Pandang, dan Balikpapan. Bahkan dibandingkan dengan BPR dan BRI Unit Desa, peran Perum Pegadaian dalam memberikan pinjaman cenderung tidak mengalami penurunan. Hal ini menunjukkan bahwa aktivitas pegadaian ternyata mampu menjadi semacam komplemen dari kegiatan pembiayaan yang dilakukan oleh perbankan pedesaan. Penelitian juga menemukan bahwa dalam masa krisis yang lalu Perum Pegadaian juga mengalami kesulitan likuiditas. Namun, penulis berkeyakinan bahwa kesul itan tersebut hanya bersifat temporer karena pada dasarnya kelayakan usaha pegadaian cukup tinggi. Permasalahan yang dihadapi oleh Perum Pegadaian ternyata lebih bersifat struktural terutama karena luasnya jaringan kerja dan terdapatnya beberapa kelemahan prosedur pemberian gadai sehingga mereka memerlukan suatu penataan ualang yang cukup luas agar Perum Pegadaian dapat berkembang dengan lebih baik di masa depan.

Sebagai penutup, overview ini akan mengulas secara ringkas mengenai kajian awal tentang pencucian uang atau money laundering yang ditulis oleh Hariyadi Ramelan dan Defianto Ras ${ }^{5}$. Bagi Indonesia kajian mengenai proses pencucian uang dan implikasi yang

4. Satrio Wibowo dan Gunawan, "Kegiatan Usaha Perum Pegadaian dan Peranannya dalam Mendukung Pemberdayaan Ekonomi Rakyat", hal. 55

5. Hariyadi Ramelan dan Delfianto Ras, "Kajian Awal Tentang Money Laundering serta Implikasinya dalam Pasar Keuangan Internasional”, hal. 117 
ditimbulkannya cukup penting mengingat sistem devisa bebas yang kita anut dewasa ini memungkinkan terjadinya praktik-praktik pencucian uang terutama melalui sistem perbankan nasional. Paling tidak kita dapat menduga praktik sedemikian mungkin saja dapat terjadi sejalan dengan tingginya arus masuk dan keluar modal melalui perbankan nasional terutama dalam beberapa tahun terakhir dan dalam situasi krisis yang lalu. Oleh karenaitu, meskipun tidak diuraikan di dalammakalah setidaknya penulismengakui bahwa pencucian uang ini dapat menimbulkan dampak makro maupun mikro, antara lain berupa ketidakstabilan fungsi permintaan uang beredar, volatilitas arus modal yang tidak terduga dan risiko pada kesehatan perbankan nasional. Oleh karena itu, selain karena alasan ketidakpatutan dan yuridis, upaya pencegahan dan pemerangan terhadap kegiatan pencucian uang memiliki dimensi ekonomis pula. Diakui bahwa upaya memerangi praktik ilegal ini tidak mudah. Oleh karena itu penulis menyatakan bahwa tindakan yang paling efektif dalam menangkal pencucian uang adalah mendeteksi sedini mungkin aktivitas kriminal tersebut pada awal prosesnya, yaitu saathasil-hasil ilegal tersebut masuk kedalam sistem perbankan. Dalamkonteks inilah maka di samping upaya memonitor arus lalulintas modal dan memperkuat sistem pengawasan perbankan, pendekatan 'know your customer rule' oleh perbankan seharusnya menjadi pilihan yang terbaik untuk memerangi kegiatan ilegal tersebut. 